\title{
Tracking and Mapping the Position of Knowledge Workers' Agencies in New Media
}

\author{
Zudan Rosyidi' ${ }^{1}$, Murni Fidiyanti ${ }^{2}$, Husni Abdillah ${ }^{3}$, Abd. Halim ${ }^{4}$ \\ zudanrosyidi1@gmail.com ${ }^{1}$,murnifidiyanti@uinsby.ac.id ${ }^{2}$, abdillahhusni.ha@gmail.com³ \\ halim@uinsby.ac.id ${ }^{4}$ \\ State Islamic University of Sunan Ampel Surabaya
}

\begin{abstract}
This paper tracks and maps the position of knowledge agency that conducts activities in new media by basing on the results of analyzing articles in journals and books. The results of the analysis show that there are two trends in the behavior of new media users. First, making cyber activities a form of pleasure. Take time and add ideas or concepts to the previously existing content or create new content. Second, new media owners unconsciously exploit them. New media owners with the proper wages of a worker do not convert the resulting surplus of economic value.
\end{abstract}

Keywords: Agency, Knowledge Workers, New Media.

\section{Introduction}

The proliferation of knowledge workers gave rise to the reality of Internet agencies that could be classified as unpaid workers[1]. Terranova says, "free labor is the moment that is pleasurable and productive activities that are pleasurably embraced and the same time often shames exploited[2]. This agency consumes knowledge, which at a certain stage turns into a creative production process that can be classified as a form of invisible exploitation, which in the end the impression that arises is a pleasure. They become unaware that the activities carried out are forms of work because they produce surplus value in the form of money for other parties.

Knowledge worker refers to person who uses new media to create content and share it for free[3]. Not only is it related to influencing the distribution of knowledge, but it is also related to the management of knowledge and collaborative patterns. How knowledge workers in their work environment use networks, information seeking, and generalization of ideas that might influence creativity, knowledge creation, and innovation in the creative process.

The economic value is not a push factor in the activity process that leads to this "free labor". Ritzer and Jorgensen say that users of media platforms on the internet prefer the exchange of more value generated in the process of activity on the internet with goods and services[4]. Self-motivation to connect yourself with others, career development, or as a campaign against projects that are being worked on[3].

The tangible form of creative production is the production and reproduction of media content. They write news, share experiences, translates to do creative works which then obscure their position as consumers of a media. Ritzer and Jorgensen positioned the agency's actions in new media as producers and consumers at the same time[3]. They have multiple identities, as 
producers and consumers. It means, these agents enjoy a product (item) and on the other hand they do work to give more value to the item.

With the framework of Ritzer and Jorgensen, the work of knowledge workers is no longer mechanical in following procedures or following the work lines set by institutions or institutions. This activity is individualistic in accordance with the competencies of each internet user. In addition, work can also be done anywhere and not necessarily in companies with the use of information technology, both software and hardware.

\section{Results}

\subsection{Knowledge Workers's Agencies : From "Free Labor" to "Prosumer"}

The emergence of knowledge workers is a symptom that developed in the early 20th century when capitalism began to develop. This group of workers is part of the Research and Development (R \& D) department of the company. They have the main task of making discoveries that can be used for efficiency and work effectiveness which ultimately can maximize company profits. The next development is the emergence of laboratory-based companies that recruit experts to produce innovation and creation[5]. This involvement moves even more massive along with the application of communication information technology that is used to carry out the process of reorganizing the work organization.

The representation of "free labor" can be identified by the self-service concept used by fast food restaurants. Consumers who shop for food in restaurants are required to carry out their work in the production chain that should be done by restaurant workers. Taking food, sauce, disposing of food waste is a form of work done by consumers. In traditional restaurants, consumers who come will be served adequately. They sit, choose, eat, and pay for the food ordered.

The tendency of the emergence of consumers who work is an advanced form of the development of capitalism that develops in such a way as to obscure the boundary between production activities (producers and inside there are workers) and consumption (consumers). The phenomenon of the placement of consumers in the production work system can also be found in several other activities. Commonly found in American consumers who refuel themselves at refueling stations taking money at ATMs, using electronic kiosks to purchase certain goods and services, and using medical devices independently such as blood pressure, and carry out pregnancy tests. Ritzer and Jorgensen use the term "prosumer" to describe the phenomenon.

"Prosumer" is the newest form of capitalism which gives rise to a condition in which between producers (in it are workers) and consumers become blurred by the main characteristic that stands out is the emergence of unpaid labor/ free labor. They try to make a profit from unpaid work from activities carried out by consumers while carrying out the consumption process and try to pay little to work done by the workers.

Since the founding of Internet 2.0, the technology-based industry of the Internet has more role as a mediator and makes its users participate more or what is known as user-generated. The position and function of this user are not found in the initial phase of the Internet. Internet 2.0 does not create "presumption" but provides space for involvement and popularity as well as developing consumer capacity. There are various examples of industries that use this pattern with differentiation in the work area that can be used related to the divided space. Wikipedia 
provides an opportunity for users to participate in editing, updating data and submitting comments. Social media such as Facebook, MySpace, Twitter, and other social media provide space on the internet for users to create profiles in the form of videos, photos, and texts, interact with others, and to build communities, and Web blogs and Micro blogging (Twitter) provide reviews of things (food, clothing, shops, companies, services) that are intended for those who will use them.

For capitalism, a website that is a medium that can be used by internet users to strengthen user competencies that can be known and assessed by many people who are connected to their web which ultimately allows them to become professionals with high income. With a web site, users can promote themselves. It was the reason why the capitalism did not pay them.

Furthermore, free spaces on the Internet can also be used for economic purposes such as those carried out by e-Bay and Amazon.com. An e-Bay site that can be used by consumers to create markets and Amazon.com that encourages consumers to get involved in work during the order process and provide review articles on an item.

\subsection{Work of Knowledge Worker}

The internet provides a wider space of freedom, autonomy, creativity and collaboration compared to existing media. New media is not like old media that controls consumers in terms of content, distribution, and interaction. Social media is run in the form of interdependence between individuals through forms of interaction and participation.

In digital space, individuals talk about everything and position themselves as experts in their fields. Each individual constructs his knowledge with imagination in the form of reality that he wants to form. They do new groupings and redefine their historicity along with the creation of new social relations which ultimately give new meaning to self-identity.

Knowledge workers make work processing information and ideas as their production base. Collectively they carry out the production process and adding value to the initial platform of knowledge that already exists on the internet[2]. All segments of society can access and use the Internet to construct and reconstruct themselves.

With knowledge, this agency produces or reproduces text and distributes it through various media platforms on the Internet. Gonzalez looks at the intentions and motivations of agency workers to translate new media content with local languages by not following a growing global discourse[1]. Dean looked at the figure of Asley Quals who used his knowledge to spearhead new mainstream content amid an abundance of similar information[6]. Lim saw social activists using cyberspace to fight against the ruling regime in Indonesia[7].

All forms of knowledge are on the Internet. All individuals can share insight on the Internet. The openness of new media as the entrance for users to disseminate information with the addition of time and cost factors[8]. In his research, Virginia got informants whose lives were based on information and knowledge on the Internet that had various facilities and did not need to complicate themselves by looking for references to books that took a long time to the knowledge they wanted to acquire and put into practice.

Nevertheless the internet is not the main source. Some studies show that knowledge workers make other reference sources in information retrieval. They make these sources as part of the work process. Mouroner maps three spaces that are defined as sources of information search[3]. 
Table 1. The Sources of information of Knowledge Workers

\begin{tabular}{|c|c|c|}
\hline Internet & Direct conversations & Conferences \\
\hline $\begin{array}{l}\text { 1. Search engines } \\
\text { 2. Websites } \\
\text { 3. Newsletter } \\
\text { 4. Wikipedia } \\
\text { 5. Scientific journals }\end{array}$ & 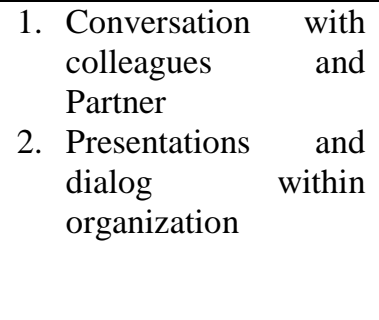 & $\begin{array}{l}\text { 1. Knowledge on what } \\
\text { others do } \\
\text { 2. Information can be } \\
\text { combined with own } \\
\text { work Sharing of } \\
\text { interesting problems } \\
\text { and challenges with } \\
\text { others }\end{array}$ \\
\hline
\end{tabular}

The knowledge is constructed individually or in groups. They are involved in collaborative work. They communicate, exchange knowledge both inside and outside the organization.

Knowledge is disseminated through informal means that do not follow conventional standards like the learning process in schools and have different benefits between individuals[9]. It is also possible for internet users to participate in enriching existing knowledge without having to think about scholarship on the content uploaded on the internet because of the principle of usefulness.

Not all knowledge shared by internet can be understood as an overall idea, idea, or concept of a phenomenon. Readability is inseparable from sharing behavior on the internet and the substance of the knowledge shared itself. Sharing has two meanings, as distributive and communicative activities (communication). With distribution, agencies on the internet only sort out the knowledge they want to share and then share it with others. The communication aspect is more as a continuation of the symbolic interaction model that is replaced by new media.

\section{Conclusion}

The position of knowledge workers is at two poles. First, the position that requires him to make as much as possible new media content without the clarity of his position in the new media structure. Second, they build their competence from the activity of creating new media content which ultimately increases the skill and understanding of the agency on one problem.

One of the fundamental critics toward the study that uses the concept of free labor is exploitation is not merely related to the loss of potential monetary value, but also the loss of opportunities to control the production process and creativity. The study also failed to see the differences between the concept of free labor with promotional work carried out by fans in the case of indie music, and other activities on the internet.

\section{References}

[1] L. Pérez-González, "Amateur Subtitling As Immaterial Labour In Digital Media Culture," Converg. Int. J. Res. into New Media Technol, vol. 19, no. 2, pp. 157-175, 2013.

[2] T. Teranova, "Free Labor: Producing Culture for the Digital Economy," Soc. Text, vol. 18, no. 2, pp. 33-57, 2000.

[3] O. Mauroner, "Social Media For The Purpose of Knowledge Creation and Creativity Management-A Study of Knowledge Workers In Germany," Int. J. Learn. Intellect. Cap, vol. 13, 
no. $2-3$, pp. $167-183,2016$.

[4] G. Ritzer and N. Jurgenson, "Production, Consumption, Prosumption," J. Consum. Cult., vol. 10, no. 1, pp. 13-36, Mar. 2010

[5] E. Mendel, Late Capitalism. London: Verso Book, 1975.

[6] J. Dean, "Whatever Blogging," in Digital Labor: The Internet As Playground and Factory. London: Routledge, 2013.

[7] M. Lim, "Cyber-Civic Space in Indonesia: From Panopticon to Pandemonium," Int. Dev. Plan, 2002.

[8] A. Virginia, "Pergeseran Budaya Komunikasi pada Era Media Baru: Studi Kasus Penggunaan Facebook oleh Digital Natives.," J. Komun. Indones., vol. Nov 6, pp. 77-86, 2017.

[9] F. L. Nikolou-Walker E, "Beyond borders: expanding the uses of work-based learning," in Education and Social Change: Connecting Local and Global Perspectives, E. Geoffrey, Ed. New York, London: Continuum, 2010, p. 314. 